Marek Sokołowski

Uniwersytet Warmińsko-Mazurski w Olsztynie

ORCID: 0000-0003-2658-9880

\title{
Jeziora osobliwej muzyki. Zastosowanie nowoczesnych narzędzi crowdfundingu w projekcie Ania Broda "Thousand Lakes". Studium przypadku
}

\begin{abstract}
Streszczenie
Artykuł stanowi studium przypadku (case study) opisujące projekt poustania płyty muzycznej „Thousand Lakes” autorstua Ani Brody. Płyta składająca się z duudziestu utworów zawiera muzykę tradycyjną z Warmii i Mazur. Poustanie płyty było możliue dzięki uykorzystaniu nowoczesnego sposobu pozyskiwania funduszy, jakim jest croudfunding, oparty na zasadzie kultury współtworzenia. Dzięki wykorzystaniu nowoczesnych mediów społecznościowych i zaangażowaniu wielu ludzi artystka zgromadziła niezbędne środki finansowe potrzebne do nagrania płyty.
\end{abstract}

Słowa kluczowe: crowdfunding, kultura uspółtworzenia, nowe media, muzyka ludowa, Thousand Lakes, Ania Broda.

\section{Lakes of peculiar music. The use of modern crowdfunding implements in the Project Ania Broda "Thousand Lakes". Case study}

\begin{abstract}
The article is a case study describing Ania's Broda music CD project "Thousand Lakes". The album consists of tuenty songs, contains traditional music from Warmia \&Mazury. The creation of the album was possible thanks to the modern way of acquiring funds in the form of croudfunding. This implements that it is based on a new type of culture called the culture of co-creation. With the help of modern social media and by engaging many people, the artist gathered the necessary financial recourses needed to make a CD.
\end{abstract}

Keywords: crowdfunding, culture of co-creation, new media, folk music, Thousand Lakes, Ania Broda. 


\section{Wprowadzenie}

Celem artykułu jest próba wykazania, jak nowe media upłynęły na rozwój nieznanych ucześniej form aktywności społecznej, takich jak opisane u tekście zbiórki crowdfundingowe, które nie istnieją poza przestrzenią internetową. Dzięki wirtualnej rzeczywistości ten nowatorski sposób gromadzenia kapitału na określony cel pozwala również na mobilność idei oraz gromadzenia się wokół projektu ludzi, którzy po raz pierwszy spotykają się przy konkretnej zbiórce crowdfundingowej. Mimo że crowdfunding jest ściśle związany z wirtualnym światem, to wiele aktyuności u realizacji projektów dzieje się u świecie rzeczywistym, u postaci rozmów, spotkań, koncertów, wywiadów. To również z pomocą tych wydarzeń ogłaszanych w Internecie ludzie kumulują uspólną energię u projekcie poprzez bezpośrednie spotkania, co daje możliwość uwiarygodnienia obietnic składanych przez pomysłodaucę danego projektu.

Artykuł jest opisem studium przypadku (case study), poświęconym sposobowi realizacji folkowej płyty muzycznej, poustałej i zrealizowanej dzięki skutecznemu zastosowaniu nowoczesnych narzędzi, wykorzystujących możliwości, jakie stwarzają media społecznościoue. Studium przypadku, należąc do jakościouych metod badauczych w naukach społecznych, w tym nauce o komunikowaniu społecznym i mediach, jest niekiedy krytykowane z uwagi na brak solidnych podstaw do generalizacji wniosków, będąc jedynie wąskim wycinkiem większego obszaru. Mamy świadomość ouych ograniczeń, jednakże głóunym zamierzeniem badań, również u opisanym studium przypadku, było poznanie okoliczności występowania zjawisk, odkrycie ich przyczyn, poprzez „, kanoniczne” pytania badaucze, jakie zawsze u tej metodzie się pojawiają: kto, co, jak, gdzie, dlaczego? Wybrana metoda studium przypadku oferowała możliwość pogłębionej analizy zarówno problemu, jakim jest samo zjawisko crowdfundingu, co istotne, dopuszcza również znaczną elastyczność (z której skorzystano, skupiając się na szczegółach finansouych projektu, aby uzmysłowić skalę jego realizacji), zułaszcza gdy chodzi o nietypoury problem badauczy, a za takoury uznano sposób, za pomocą którego zgromadzono zarówno środki finansowe, jak i wydano interesujący nas album muzyczny.

\section{Finansowanie społecznościowe (albo co „zafunduje" nam tłum)}

Pieruszą akcją związaną ze społeczną zbiórką funduszy na z góry określony cel było sfinansowanie trasy koncertowej brytyjskiego zespołu rockowego Marillion, który w 1997 roku pozyskał w trakcie zbiórki internetowej ponad 60 tysięcy dolarów. Co ciekawe, z inicjatywą nie wyszli członkowie tego zespołu muzycznego, lecz jego fani. Mimo że zespół nie był w akcję zaangażowany, cel został osiągnięty bardzo szybko. Podczas nagrywania kolejnej płyty członkowie grupy rozesłali mailing do 30 tysięcy fanów znajdujących się w ich bazie danych z prośbą o dokonywanie zamówień u formie 
przedsprzedaży. W wyniku tej akcji Marillion pozyskało 100 tysięcy dolarów, dzięki którym muzycy byli w stanie nie tylko pokryć koszty nagrań, ale jednocześnie zebrana suma pozwoliła im na uniezależnienie się od wytwórni płytouych i innych pośredników, którzy wcześniej mieli duży upływ na działania zespołu. Tym samym akcja zbierania pieniędzy wśród internautów (kolejne płyty były wydawane w podobny sposób) stanowi jeden z pierwszych przykładów finansowania społecznościowego, zainicjowanego oddolnie przez miłośników zespołu ${ }^{1}$. Skala przedsięuzięcia przerosła oczekiwania artystów, jednak ich prekursorski pomysł pomógł zaszczepić nowy model działania integrującego wielu ludzi wokół projektu, pomagających poprzez suoje drobne upłaty osiągać ważne i wartościoue dla nich cele².

Na fali sukcesu uspomnianego przedsięwzięcia w 2000 roku w USA poustała platforma internetowa artistshare.net, zajmująca się zbiórką pieniędzy dla artystów. Najpopularniejszym na świecie serwisem jest Kickstarter, powstały w 2009 roku, finansujący projekty z takich dziedzin jak filmy, animacje, gry komputerowe, planszowe i karciane, komiksy, albumy muzyczne, a także projekty powiązane ze sztuką, modą, teatrem, fotografią oraz - co istotne - nowoczesnymi technologiami, związanymi z rozuojem sieci.

W Polsce jest już dostępnych sporo publikacji na temat zaróuno samej istoty zjawiska, jak i jego strony technicznej, instruującej osoby zainteresowane, jak mogą wcielić w życie suój pomysł, realizując go z wykorzystaniem narzędzi, jakie oferuje croudfunding. Nazwa ta stanowi połączenie duóch angielskich terminów, gdzie crown oznacza tłum, a funding - fundowanie, finansowanie czegoś. Neologizm ów oznacza uspólne fundowanie czegoś i uspółfinansowanie, a także finansowe uspieranie czegoś poprzez wzięcie udziału u danym przedsięuzięciu. Jednocześnie oznacza formę finansowania organizowaną przez pewien rodzaj społeczności, która poustaje wokół tych projektów. System polega na upłacaniu drobnych, jednorazouych upłat, jakich dokonują osoby zainteresowane tematem projektu. Tematyka działań pod hasłem crowdfundingu może dotyczyć wielu zróżnicowanych sfer aktywności człowieka. Obejmuje z reguły kulturę, sztukę, biznes, naukę, podróże czy też działania społeczne. Osoba, która wymyśla projekt, często proponuje ludziom, którzy chcą jej pomóc w realizacji pomysłu, nagrody i specjalne gadżety w zamian za określoną wpłatę na konto projektu. Na wielu portalach panuje zasada udzięczności i drobnego chociażby oduzajemniania się wobec uspierających osób. Rodzaj nagrody zależy od wielkości upłaty33.

O rosnącej popularności crowdfundingu decyduje rozwój Internetu i nowych mediów. Dzięki rozwojoui sieci możliwe są rozpoczęcie i realizacja szerokich działań zarówno w przestrzeni tworzenia projektów, jak i informowania o nich nieznanych

\footnotetext{
${ }_{1}$ J. Collins, Marillion: autoryzowana biografia, przeł. K. Oszczyk, Wydaunictuo Kagra, Poznań 2004.

2 https://wuw.virgin.com/music/how-marillion-pionereed-crowdfunding-music (dostęp: 26.10.2019).

${ }^{3}$ C. Życki, Crowdfunding - nowoczesna forma finansowania start-upów, „Ekonomika i Organizacja Przedsiębiorstua" 2013, nr 12, s. 13.
} 
nam osobiście ludzi, oraz co ważne ze społecznego punktu widzenia, a co nie powinno umknąć uwadze socjologicznej - tworzenia uspólnoty osób wspierających ten sam cel, co opisywał w swoich pracach Manuel Castells ${ }^{4}$. Romantyczna wizja społeczeństua sieci? Zdecydowanie nie, chociaż przyznać trzeba, że zjawisko croudfundingu w języku potocznym określa się jako możliwość realizacji marzeń, ale w wariancie mocno nietypouym, gdyż świadomie pozwalamy innym ludziom, z uykorzystaniem nowoczesnych technologii medialnych, wspólnie z nami je realizować. To nowe zjawisko społeczne, ale też nowe wyzuanie dla nauk o mediach i komunikacji społecznej, gdyż proces budowania zaufania społecznego poprzez generowanie wspólnych sił do działania jest konstruowany w obrębie internetowej grupy, lecz o zdecydowanie odmiennej aktyuności widocznej na forach czy blogach internetouych. Społeczność crowdfundingowa zbiera się głównie wokół portali dedykowanych temu zjawisku ${ }^{5}$.

Poszczególne serwisy crowdfundingowe są już weunętrznie zróżnicowane, dlatego też specjaliści z tego zakresu uyróżniają już między innymi croudfunding dotacyjny, zakładający dokonywanie wpłat na określony cel, croudfunding oparty na nagrodach, w którym wszyscy upłacający otrzymują określony rodzaj gratyfikacji, będący świadczeniem wzajemnym za dokonaną wpłatę. Istnieje także croudfunding oparty na przedsprzedaży, gdzie uspółfinansujący dostarczają środki na stuorzenie danego produktu, który po zakończeniu działań na platformie jest im dostarczany przez twórców projektu. Crowdfunding udziałouy polega na usparciu finansouym przedsięuzięcia oraz uzyskaniu w nim udziałów w kapitale zakładowym spółki beneficjenta. Wpłata na rzecz projektodaucy i oczekiwanie na zurot, z ewentualnym zyskiem, jest nazywany croudfundingiem dłużnym ${ }^{6}$.

Już tylko z tej krótkiej charakterystyki można wnioskować, że istnieją istotne różnice pomiędzy poszczególnymi formami zbierania społecznie środków przeznaczonych na realizację danego projektu. Dotyczy on głównie procedury zbiórki funduszy. Wyjaśnijmy to na przykładzie. Serwis Polakpotrafi.pl proponuje zbiórkę, która odbywa się w ściśle określonym przez projektodaucę czasie. Jeżeli we uskazanym okresie nie uda się zebrać w pełni wnioskowanej sumy, projekt nie zostanie ufundowany, środki finansowe zaś uracają do osób je wpłacających. Odrębna forma zbiórki to system, jaki promuje portal odpalprojekt.pl. W tej formie zbiórki ma się również ściśle określony czas działania, natomiast sukces nie jest zależny od zebrania pełnej kwoty. Oznacza to, że nie uystępuje tu sytuacja porażki, ale sam projekt, z uwagi na nikłość zebranych środków może nie być zrealizowany.

Od strony technicznej wprowadzenie projektu do realizacji w serwisie croudfundingouym wcale nie jest szybkie i proste. Portale na początek przepuszczają dany projekt

\footnotetext{
${ }^{4}$ M. Castells, Społeczeństwo sieci, przeł. M. Marody i in., Wydawnictwo Naukowe PWN, Warszawa 2007.

${ }^{5}$ P. Gałuszka, Finansowanie społecznościowe jako nowe wyzwanie badawcze dla nauk o mediach [w:] Film i media - przeszłość i przyszłość. Kontynuacje, red. A. Guóźdź, M. Kempna-Pieniążek, Wydawnictwo Instytutu Sztuki PAN, Warszawa 2014, s. 131.

${ }^{6}$ D. Dziuba, Finansowanie społecznościowe: oferta emisji akcji dla przedsiębiorstw spotecznych, „Transformacje” 2016, nr 1/2, s. 269-270.
} 
przez system akceptujący jego formę i treść. Istnieją określone wytyczne dotyczące formy przekazywania treści na stronach crowdfundingouych z użyciem takich narzędzi jak filmy i zdjęcia. Zamierzając wprowadzić projekt do sieci jego pomysłodawca i potencjalny wykonawca spotyka się na początku z konsultantem do spraw przygotowania projektu, który stara się pomóc we właściwym przygotowaniu całości przedsięuzięcia. Każdy element projektu ma upływ na jego powodzenie i do każdego proponuje się podejść z jednakową uwagą. Jak zauważają i przestrzegają konsultanci, bez zrozumienia narzędzia, z którego zamierza się skorzystać, bardzo trudno będzie zrealizować dany projekt. Dlatego też ma się do czynienia z pewną filozofią croudfundingu, swoistym rozumieniem całego systemu działania i mechanizmów decydujących o ich skuteczności.

Crowdfunding istnieje i rozwija się nie tylko dzięki samemu istnieniu Internetu, ale głównie portali społecznościowych, które generują uczestników działań, zachęcają do aktyuności, propagują peune uzorce postępowania? Ten rodzaj aktyuności, u postaci zbiórki crowdfundingowej nie byłby możliuy poza przestrzenią internetową, jest ściśle związany z rozwojem nowych mediów i nieustannie ewoluuje. Dzięki wirtualnej rzeczywistości taki rodzaj gromadzenia kapitału na określony cel, z pomocą datków zebranych wśród „cyfrowego tłumu”, jest nieobjęty opodatkowaniem. Ale głównie chodzi o spopularyzowanie idei, zgromadzenia społeczności, jej mobilizację wokół pomysłu, a zatem ludzi, zainteresowanych tym samym projektem, który ich zaciekawił, zaintrygował, u jakiś sposób poruszył, że są skłonni zaangażować weń własne pienią$\mathrm{dze}^{8}$. Rosnąca popularność crowdfundingu spowodowała wyodrębnienie się swoistej kultury wokół realizowanych projektów i można nazwać ją kulturą współtworzenia, gdyż skupia ludzi tych samych idei, wyznawanych wartości. Budowane są sieci wzajemnych relacji, oparte na informacji, zaufaniu, mobilizacji. Przekazywanie informacji i gromadzenie się osób wokół projektu jest najsilniejsze zuykle na początku działań, w momencie ogłoszenia oficjalnej zbiórki następuje duże zainteresowanie oraz szybki przekaz informacji. Internauci interesują się nowym projektem, kiedy zaczną się z nim identyfikować, odczuwać emocjonalnie, mówić o nim w gronie swoich znajomych, można zakładać, że odniesie on sukces.

Bez rozwoju mediów społecznościouych trudno byłoby oczekiwać, aby na realizację własnych marzeń, w postaci wydania książki, nagrania albumu muzycznego, zrealizowania filmu, można otrzymać fundusze od nieznajomych osób, które nie oczekują w zamian niczego, co przeuyższałoby wpłaconą kwotę. Być może formy takie jak kredyt bankouy czy pożyczka powoli ustępują miejsca akcjom, w którym nieznani sobie ludzie zaczynają uspólnie działać celem zrealizowania konkretnego zamierzenia99.

Croudfunding jest legalną formą działania w Polsce i w przeciuieństwie do zbiórek publicznych w tym systemie zakłada się, że na osoby wspierające czeka nagroda.

\footnotetext{
7 P. Świątek, Crowdfunding, czyli o biznesie słów kilka, „Notatnik Teatralny” 2015, nr 77, s. $133-134$.

8 A. Brunello, Crowdfunding: podręcznik, Wydawnictwo CeDeWu, Warszawa 2016, s. 46-47.

9 J. Adamska-Mieruszeuska, U. Mrzygłód, Wykorzystanie finansowania społecznościowego w latach 2011-2014, „Zeszyty Naukoue Uniwersytetu Szczecińskiego” 2014, nr 67, s. 763.
} 
Jednakże należy przypomnieć, że udział i korzystanie z danego serwisu nie jest bezpłatne, gdyż jest pobierana opłata procentowa od sumy, jaka zostanie uzbierana w czasie akcji croudfundingowej ${ }^{10}$.

\section{Kultura współtworzenia}

Niewątpliuy fenomen społeczny, jakim jest tworzenie się pewnej społeczności wokół danego projektu crowdfundingowego, ma swoje źródła w szerszej koncepcji crowdsourcingu, w którym społeczność jest traktowana jako źródło rozmaitych zasobów. Mimo że literalnie crowdsourcing jest pojmowany jako wykorzystanie zbiorowości internetowej przez dany podmiot, nie sposób jednoznacznie stwierdzić, czy darczyńcy, którzy z ułasnej woli przekazują komuś pieniądze, czuli się w jakikolwiek sposób wykorzystywani. Zakłada się, że satysfakcja uczestnika zbiórki może być albo społeczna, polegająca na uzyskaniu rozpoznawalności i rozgłosu, albo ściśle ekonomiczna, przynosząca wymierny sukces finansowy. Ale też indywidualna, związana z rozwojem własnych umiejętności i ze wzrostem poczucia własnej wartości. Dlatego też specjaliści zajmujący się sygnalizowaną problematyką stwierdzają, że w croudfundingu uystępuje durubiegunowe działanie społeczne, gdzie uspólnie rozwiązuje się problemy, a zbiorowość korzysta z pomysłów i wiedzy pozostałych uczestników danej zbiórki oraz ich kapitału ${ }^{11}$.

W obecnych realiach społecznych i kulturouych coraz więcej osób, zachęconych sukcesem, jaki na tym polu odnieśli inni, próbuje wydać swoją pieruszą książkę w modelu self-publishing. Model ten okazuje się atrakcyjny nie tylko dla osób poszukujących darczyńców, lecz także dla nich samych, dając im możliwość przyczynienia się do sukcesu kogoś, kto ich zdaniem najbardziej na to zasługuje. Jak wynika z wielu doświadczeń osób, które u ten sposób pozyskiwały środki na swoje projekty, pozyskiwaniu niezbędnych funduszy towarzyszy częstokroć poznanie ciekawych osób, zawarcie nowych znajomości, zebranie dużej ilości pozytywnych komentarzy, ale też wypromowanie siebie i swojego dzieła lub zrealizowanie swojej pasji, ale tym razem z wydatną pomocą innych ludzi. Za najbardziej optymalny czas, jaki należy przeznaczyć na zbiórkę, uważa się okres trzydziestu lub czterdziestu dni, chociaż wielu crowdfunderów, czyli osób, które organizują zbiórki, woli działać w krótszym czasie, lecz na większą skalę. W każdym przypadku ważne jest posiadanie odpowiedniego przygotowania i dobrej strategii marketingowej ${ }^{12}$.

${ }_{10}$ P. Staszczyk, Crowdfunding a prawo polskie: kilka watpliwości, „Trzeci Sektor” 2016, nr 1, s. 71-73.

${ }^{11}$ M. Frańczuk, Crowdfunding - finansowanie społecznościowe: zarys instytucji $w$ świetle polskich regulacji prawnych, „Zeszyty Naukowe Uniwersytetu Ekonomicznego w Krakowie” 2014, nr 6, s. 48-49.

${ }^{12}$ K. Kozioł-Nadolna, Crowdfunding jako źródto finansowania innowacyjnych projektów, „Zeszyty Naukowe - Uniwersytet Szczeciński. Finanse, Rynki Finansowe, Ubezpieczenia” 2015, nr 73, s. 672-673. 
W takim ujęciu finansowanie społecznościowe polega na zrzeszaniu $w$ jednym miejscu, na uybranym, specjalistycznym portalu podmiotów, które poszukują kapitału dla swoich projektów zainspirowanych rozmaitymi obszarami życia społecznego. Obecnie do najpopularniejszych kategorii projektów zalicza się podróże, książki, wydarzenia, filmy, gry, technologie i edukację ${ }^{13}$. Najczęściej źródła finansowania projektów są zdywersyfikowane, co oznacza, że mało który crowdfunder u całości opiera suój pomysł na usparciu społeczności, która zaakceptuje jego przyszłe przedsięwzięcie, mając świadomość, że croudfunding najczęściej pokryje tylko część spodziewanych kosztów, wysokich na przykład w sytuacji uruchomienia produkcji nowoczesnego gadżetu lub technologicznej nowinki, wymagającej zbudowania prototypu, następnie zaś udrożenia go do produkcji ${ }^{14}$.

Od crowdfunderów nie wymaga się, by rozliczyli się z zebranych pieniędzy, jednakże osoby, które zajmują się zbiórkami, najczęściej tak robią, pragnąc być szczerymi wobec wspierających i wypaść wśród nich wiarygodnie. Z tego powodu zaleca się rozpisać strukturę kosztów i zobrazować, dlaczego kwota projektu została ustalona w konkretnej uysokości oraz udowodnić, że za zebrane środki projekt uda się zrealizować. Darczyńcy oczekują, by crowdfunderzy byli dokładni i precyzyjni w swoich wyliczeniach projektouych i jest to wiodący wyznacznik ich przychylności. Ważne jest, aby uprowadzić różnorodność nagród zarówno za uysokie, jak i niskie kwoty usparcia. Do najbardziej atrakcyjnych nagród, jakie oferuje się uspierającym, zalicza się nie przekazywane gadżety, w postaci kubków czy koszulek, lecz ułasne uspółuczestniczenie w realizacji danego projektu. W przypadku osób będących twórcami i artystami dobrze sprawdzają się uszelkie pamiątki, mające ścisły związek z procesem twórczym.

Z przeprowadzonych badań nad społecznością crowdfundingową wiemy, że darczyńcy oczekują od projektów czterech podstawowych rzeczy. Po pierwsze, osoba, którą wesprą finansowo, musi uydać się im szczera, dlatego starają się zorientować, czy projektodawca faktycznie potrzebuje pieniędzy i czy zostaną one rozsądnie wykorzystane. Istotnym czynnikiem, podlegającym ocenie jest również zaangażowanie inicjatora projektu oraz posiadanie dużego wkładu własnego. Profesjonalne podejście to kolejny element wymagany przez potencjalnych beneficjentów, którzy chcą mieć pewność, że dobrze zainwestują swoje pieniądze, zakładając, że osoba, która je otrzyma, spożytkuje je u taki sposób, w jaki się deklarowała. Ostatnim, nie mniej ważnym elementem branym przy ocenie projektów, jest wartość dodana oznaczająca nie tylko fundusze, które otrzyma croudfunder, lecz także jego osobisty wkład u społeczność implikowany czy też wzmocniony tym, co pragnie zrobić: nagrać płytę, zrealizować film lub wystawę fotografii ${ }^{15}$.

${ }^{13}$ D.T. Dziuba, Rozwój systemów crowdfundingu - modele, oczekiwania i uwarunkowania, „Problemy Zarządzania” 2012, nr 3, s. 88 i nast.

${ }_{14}$ D. Kordela, Crowdfunding w Polsce: koncepcja finansowania społecznościowego [w:] Rachunkowość na rzecz zrównoważonego rozwoju: gospodarka, etyka, środowisko, red. D. Dziawgo, Wydawnictwo Uniwersytetu Ekonomicznego, Wrocław 2016, s. 145-146.

${ }_{15}$ B. Brzozouska, Crowdfunding and crowdsourcing: New chalelenges for the visual documentacion of the city cultures, ,Przegląd Kulturoznawczy” 2013, cz. B, s. 296. 


\section{Jeziora osobliwej muzyki. Ania Broda „Thousand Lakes”}

Panuje przekonanie, że crowdfunding jest dedykowany głównie znanym i już uznanym twórcom, jednak artystyczny sukces olsztynianki Julii Marcell (pseudonim artystyczny) udowadnia, że nieznana wcześniej utalentowana wokalistka muzyki alternatywnej mogła w 2007 roku dzięki internautom i portalowi sellaband.com w krótkim czasie zebrać 50 tysięcy dolarów, co pozwoliło jej na uyprodukowanie pierwszego profesjonalnego albumu, debiutanckiej płyty „It Might Like You”, nagranej w Berlinie. Artystka twierdzi, że finansowanie społecznościoue samo w sobie jest doskonałym pomysłem, jednak nie zausze wystarczy zebrać pożądaną sumę do tego, by dany artysta faktycznie osiągnął sukces ${ }^{16}$.

Interesujący nas projekt, zrealizowany pod postacią płyty „Thousand Lakes”(„Tysiąc jezior"), na portalu Polakpotrafi. pl jest autorstua Ani Brody (pseudonim artystyczny). Artystka, obdarzona niepoutarzalnym głosem, posługuje się techniką śpieuu „białego”, czyli śpiewokrzykiem, techniką wokalną typową dla muzyki ludowej. Jest nie tylko kompozytorką, lecz także autorką tekstów, które sama aranżuje, zarazem jest uważana za mistrzynię gry na cymbałach wileńskich. Uprawia muzykę etno, jazz, folk, pop i muzykę dla dzieci. Jest uspółzałożycielką legendarnej już formacji „Bractwo Ubogich” i „,Kapeli Brodów", urodziła się w Olsztynie, a wychowała na warmińskiej usi Jonkowo. Jako lokalna patriotka promuje tradycyjną muzykę popularną niegdyś na Warmii, którą uważa za istotny element swojego urodzenia, zamieszkania i tworzenia. Do momentu nagrania „Thousand Lakes” miała już na koncie sześć nagranych płyt. W projekcie muzycznym „Ania Broda o Północy - Dialogi z Kolbergiem” nawiązała do kultury muzycznej północnej Polski. Albumy „Litwa”, „Mazury Polskie” i „Pomorze” stały się dla niej tematem do muzycznych dialogów i wielką inspiracją. Warmię określa jako miejsce jej identyfikacji kulturowej, a zarazem „krainę nie opisaną muzycznie w oddzielnym tomie prac dziewiętnastowiecznego etnografa" ${ }^{17}$. W dołączonej do płyty „książeczce” z tekstami utworów tak pisze zarówno o sobie, jak i zrealizowanym już wówczas przedsięuzięciu artystycznym:

Całe życie słyszałam, że na Warmii i Mazurach nie ma ciekawej muzyki. Nic bardziej mylnego! Urodziłam się u samym sercu Krainy Tysiąca Jezior. Nadal tu mieszkam i kocham to miejsce. Jako muzyk dużo podróżuję, ale zausze uracam do przestrzeni, z którą od dziecka łączą mnie miliony uspomnień. Grając od wielu lat muzykę folkową z całej Polski zdałam sobie sprawę, że brakuje u niej muzyki warmińskiej i mazurskiej. Pomyślałam - to dziwne, trzeba to natychmiast naprawić! Zaczęłam szukać i zamiast niemieckich walczykóu znalazłam skarby:) Wpadłam na trop rzadkich i starodawnych w formie hymnów warmińskich. Zafascynowały mnie melodie, energia tej muzyki, jej szlachetność, dojrzałość, głębia... Są tu pieśni inspirowane zjawiskami natury. Są pieśni Marcinkowe, związane z głęboko zakorzenioną tradycją kończenia i odnawiania umów czeladniczych i gospodarskich. Są rytmy

${ }_{16} \mathrm{Na}$ ten temat zob. K. Król, Crowdfunding. Od pomysłu do biznesu dzięki społeczności, croudfunding.pl. Warszawa 2013 [dokument elektroniczny].

${ }_{17}$ A. Kowalska, „Zróbmy to razem!”. Kultura crowdfundingu - studium przypadku [praca niepublikowana], Olsztyn 2017, s. 43. 
łamane, nietypowe frazy i ślady dawnej obrzędowości tych ziem. Trop dla odnalezienia funkcji muzyki w kulturze. Są dzikie i dynamiczne wiwaty, szalone rytmy taneczne ${ }^{18}$.

Na płycie zatytułowanej nie regionalnie, a po angielsku „Thousand Lakes” znalazło się duadzieścia melodii, $w$ tym między innymi pieśni miłosne, ballady, tańce weselne, tańce pasterskie, muzyka instrumentalna, wiwaty, kołysanki, zabawy dziecięce, kolędy, hymny adwentowe, pieśni dziadouskie oraz pieśni o rzeczach ostatecznych. W swojej pracy, polegającej na gromadzeniu i poszukiwaniu regionalnych warmińskich pieśni, artystka korzystała z archiwów Instytutu Sztuki PAN, zapisów Kolberga, własnych badań terenouych oraz archiwów muzycznych Polskiego Radia Olsztyn.

Wśród osób zaproszonych do projektu znaleźli się czołowi muzycy polskiej sceny folkowej. Oprócz Ani Brody (śpiew, cymbały wileńskie, realizacja, pomysł i aranżacja całości), wystąpili Iwona Sojka (skrzypce), Jacek Mielcarek (klarnet, saksofon, duduk), Kuba Mielcarek (basy), Mateusz Szemraj (oud, rubab), Maciej Kierzkouski (bębny, dzwonki). Nagrania do płyty zostały zrealizowane jesienią 2014 roku u studiu S4 Polskiego Radia, przy uydatnej uspółpracy radiowego Centrum Kultury Ludowej Polskiego Radia oraz 2 Programu Polskiego Radia. Nad realizacją nagrań czuwali Eua Guziołek-Tubelewicz i Jacek Gładkouski. Materiał na płytę Ania Broda zebrała i przygotowała w ramach stypendium Urzędu Marszałkouskiego w Olsztynie.

Jak każdy projekt croudfundingowy także i ten, w postaci płyty, wymagał zebrania określonej kwoty, która w tym uypadku wynosiła 13 tysięcy złotych. Fundusze zbierane na wydanie płyty miały pozwolić na: mix i mastering (3 tys. zł), projekt graficzny okładki i przygotowanie książeczki (z tekstami utworów) do druku (1 tys. zł), tłoczenie matrycy i wydanie tysiąca egzemplarzy płyty (6 tys. zł), koszty księgowości, hologramu, paska kreskowego i uprowadzenia płyty do obiegu sklepowego (1,5 tys. zł), przygotowanie plakatów i ulotek informacyjnych (1,5 tys. zł). W założeniach projektu zaznaczono również, że jeżeli uda się uzbierać uiększą kwotę, niż zakładano, zostanie ona przeznaczona na nagranie profesjonalnego teledysku i wypromowanie płyty.

Podsumowanie zbiórki pieniędzy opublikowane na portalu Polakpotrafi.pl informuje, że wydanie płyty wsparło 234 darczyńców, od których zebrano 14 tysięcy 691 złotych, zbiórkę zaś zakończono 20.05.2015 roku. Interesujące będzie podanie nie tylko wysokości zgromadzonych kwot od poszczególnych osób, lecz także dane ilościowe, w którym przedziale finansowym znalazła się określona grupa darczyńców. Wsparcie w kwocie 1 złotego lub więcej wyszło od trzynastu darczyńców, którzy mieli świadomość, że przy tak nikłym zaangażowaniu finansourym nie mogą oczekiwać żadnej nagrody. Wsparcie w kwocie 10 złotych lub więcej zadeklarowało siedmiu wspierających. Podziękowania dla tej kategorii darczyńców obejmowały autorskie podziękowania przesłane drogą mailową oraz autorskie podziękounia zamieszczone na profilu Ani Brody na portalu społecznościouym Facebook. Wpłaty w kwocie 25 złotych i więcej dokonało 25 osób. Podobnie jak u poprzedniej kategorii darczyńcy otrzymali autorskie podziękowania,

${ }_{18}$ A. Broda, Thousand Lakes ptyta z muzyka tradycyjna Warmii i Mazur, 2016 Polskie Radio SA i Ania Broda Production, s. 3. 
ale też przesłano im płyty w formacie mp3. Wsparcie w kwocie 35 złotych lub więcej wyszło od 126 osób i z zestawienia wynika, że była to najbardziej popularna forma usparcia. Tej grupie, oprócz już wymienionych wcześniej form, zaproponowano przesłanie pocztą płyty na nośniku CD, już po zakończeniu projektu. Kwota 60 złotych lub więcej wyszła od 48 osób wspierających, którym dodatkowo, oprócz gotowej płyty zaproponowano darmowy bilet na najbliższy koncert. Kuota 80 złotych lub więcej wyszła od pięciu darczyńców i upoważniała dodatkowo do otrzymania bonusowej nagrody, w postaci ręcznie malowanej drewnianej zabawki-zwierzaka, w postaci lisa, konika, żyrafy, słonia, wielbłąda wraz z ręcznie szytą lalką Gniewki Racimirowej. Przekazanie 90 złotych lub więcej (dwóch darczyńców) guarantowało oprócz płyty specjalny voucher na godzinę jazdy konnej u Pałacu Pacółtowo Luxury Resort Spa, Ośrodek Jeździecki, położonym nieopodal pól Grunwaldu i Wzgórz Dyleuskich.

Wpłata 105 złotych lub więcej (pięć osób) była honorowana nie tylko otrzymaniem płyty „Thousand Lakes”, lecz także inną płytą do wyboru z dotychczasouej dyskografii Ani Brody i indywidualnej lekcji śpieuru w Olsztynie trwającej 50 minut. Kwota 120 złotych lub więcej (sześć osób) upoważniała do otrzymania limitowanych ceramicznych medalionów z ludowymi motywami o wielkości 15 na $15 \mathrm{~cm}$ ufundowanymi przez Marcelinę i Rafała Mikułouskich z Fundacji Revita Warmia. Kwota 250 złotych (jeden darczyńca) dawała prawo do kolacji dla dwóch osób w uważanej za kultową olsztyńskiej restauracji Cudne Manowce, 300 złotych zaś (podobnie jeden darczyńca) guarantowała udział w warsztatach tkackich w ośrodku ekoturystycznym Na Karczaku w okolicach Biebrzy. Wpłata 350 złotych (dwie osoby), poza standardowymi nagrodami przewidywała umieszczenie nazwiska na okładce płyty, natomiast propozycja wpłaty 400 złotych nie wystąpiła, bonusy były podobne jak przy wpłacie 350 złotych. Deklaracja kwoty tysiąca złotych (wyszła od jednej osoby) przewidywała otrzymanie dodatkowo plakatu z autografami całego zespołu oraz godzinny koncert live Ania Broda solo w Warszawie lub Olsztynie. Nikt nie zgodził się na usparcie kwotą 1500 i 3000 złotych, co skłania do przypuszczeń, że nagrody za oferowane usparcie wymienionymi kwotami nie wydały się darczyńcom adekwatne do sumy, jaką musieliby upłacić bądź też darczyńcy nie mają w zuyczaju wpłacać na tego typu projekty tak dużych kwot. Jednakże przedsięwzięcie się powiodło, płyta została wydana, co należy uznać za udany przykład wykorzystania możliwości, jakie tkwią w finansowaniu społecznościouym w formie croudfundingu.

\section{Próba podsumowania}

Platformy crowdfundingowe dzięki rozwojowi nowych mediów stwarzają, co staraliśmy się wykazać na podstawie zrealizowanego przez Anię Brodę projektu muzycznego „Thousand Lakes”, niepoutarzalną możliwość pozyskiwania środków finansouych od prywatnych inwestorów. Nie dziwi zatem fakt, że finansowanie społeczne, pozwalające nowym, młodym firmom na poustawanie i rozwój, a debiutującym artystom na wydanie książki lub płyty, cieszy się coraz większą popularnością także w Polsce. 
Warunkiem udanej zbiórki crowdfundingowej jest zapewne przygotowanie innowacyjnej lub ciekawej kampanii promocyjnej, w której należy dokładnie opisać swoją propozycję oraz uykazać faktyczną innowacyjność swojego projektu. Rosnąca, również w Polsce, popularność crowdfundingu spowodowała wyodrębnienie się swoistej kultury croudfunderów, co już samo u sobie jest interesującym zjawiskiem społecznym, którą można określić kulturą uspółtworzenia projektów croudfundingouych. Internauci, skupiający się wokół tych idei, stają się jednocześnie siecią wzajemnych relacji, łączy ich informacja na temat danego projektu, który zamierzają wesprzeć finansowo, zaufanie wobec inicjatora i najczęściej zarazem jego realizatora, uzajemna mobilizacja i chęć doprowadzenia przedsięuzięcia do skutecznego finału. Zagadnienie to, tj. nowa społeczność i kultura uspółtworzenia, samo w sobie jest niezmiernie interesującą kwestią poznawczą, jednak z uwagi na ograniczoność i zakres tego opracowania zostało jedynie zasygnalizowane.

Przykład płyty Ani Brody z muzyką tradycyjną pochodzącą z Warmii i Mazur jest tego dobrą ilustracją, zarazem otuchą napawa fakt, że realizacji podlegała nie płyta z muzyką popową, hip-hopową lub rockową, która zapewne trafiłaby do szerszego grona odbiorców, ale muzyka czerpiąca swoją siłę i unikalną wartość z tradycji i historii krainy, metaforycznie nazywanej niekiedy Krainą Tysiąca Jezior. Owe symboliczne „tysiąc jezior" (thousand lakes), pełnych osobliwych dźwięków, w unikalny sposób nie tylko zagrała i wyśpiewała, lecz także odtworzyła, a może nawet zrekonstruowała na cymbałach Ania Broda, ocalając od zapomnienia muzykę rozbrzmiewającą dawniej w wielu miejscach Warmii i Mazur. Tradycyjna muzyka, która niegdyś rozbrzmiewała w przestrzeni publicznej owej krainy, została przypomniana i utrualona dzięki nowoczesnym możliwościom, jakie zaoferował rozwój nowych mediów społecznościouych i finansowemu zaangażowaniu się wielu osób w projekt crowdfundingowy „Thousand Lakes".

\section{Bibliografia}

Adamska-Mieruszewska J., Mrzygłód U., Wykorzystanie finansowania społecznościowego w latach 2011-2014, „Zeszyty Naukowe Uniwersytetu Szczecińskiego” 2014, nr 67.

Broda A., Thousand Lakes ptyta z muzyką tradycyjna Warmii i Mazur, 2016 Polskie Radio SA i Ania Broda Production.

Brunello A., Crowdfunding: podręcznik, Wydawnictuo CeDeWu, Warszawa 2016.

Brzozouska B., Crowdfunding and crowdsourcing: New challenges for the visual documentation of the city cultures, „Przegląd Kulturoznawczy” 2013, cz. B.

Castells M., Społeczeństwo sieci, przeł. M. Marody i in., Wydawnictuo Naukoue PWN, Warszawa 2007.

Collins J., Marillion: autoryzowana biografia, przeł. K. Oszczyk, Wydawnictuo Kagra, Poznań 2004.

Dziuba D., Finansowanie społecznościowe: oferta emisji akcji dla przedsiębiorstw społecznych, „Transformacje” 2016, nr 1/2, s. 269-270. 


\section{Marek Sokołowski}

Dziuba D.T., Rozwój systemów crowdfundingu - modele, oczekiwania i uwarunkowania, „Problemy Zarządzania” 2012, nr 3, s. 88 i nast.

Frańczuk M., Crowdfunding - finansowanie społecznościowe: zarys instytucji $w$ świetle polskich regulacji prawnych, „Zeszyty Naukowe Uniwersytetu Ekonomicznego w Krakowie” 2014, nr 6, s. 48-49.

Gałuszka P., Finansowanie społecznościowe jako nowe wyzwanie badawcze dla nauk o mediach [w:] Film i media - przeszłość i przyszłość. Kontynuacje, red. A. Gwóźdź, M. Kempna-Pieniążek, Wydawnictwo Instytutu Sztuki PAN, Warszawa 2014.

https://www.virgin.com/music/how-marillion-pionereed-crowdfunding-music (dostęp: 26.10.2019).

Kordela D., Crowdfunding w Polsce: koncepcja finansowania społecznościowego [w:] Rachunkowość na rzecz zrównoważonego rozwoju: gospodarka, etyka, środowisko, red. D. Dziaugo, Wydawnictwo Uniwersytetu Ekonomicznego, Wrocław 2016.

Kowalska A., „Zróbmy to razem!”. Kultura crowdfundingu - studium przypadku [praca niepublikowana], Olsztyn 2017.

Kozioł-Nadolna K., Crowdfunding jako źródto finansowania innowacyjnych projektów, „Zeszyty Naukowe - Uniwersytet Szczeciński. Finanse, Rynki Finansowe, Ubezpieczenia” 2015, nr 73, s. 672-673.

Król K., Crowdfunding. Od pomystu do biznesu dzięki społeczności, croudfunding.pl, Warszawa 2013 [dokument elektroniczny].

Staszczyk P., Crowdfunding a prawo polskie: kilka wątpliwości, „Trzeci Sektor” 2016, nr 1, s. 71-73.

Świątek P., Crowdfunding, czyli o biznesie słów kilka, „Notatnik Teatralny” 2015, nr 77, s. $133-134$.

Życki C., Crowdfunding - nowoczesna forma finansowania start-upów, „Ekonomika i Organizacja Przedsiebiorstwa" 2013, nr 12, s. 13. 